\title{
Efficacy of some weed control methods in soybean during kharif season
}

\author{
R. Das ${ }^{*}$, B. C. Patra, M. K. Mandal, A. Pathak and A. K. Dolai \\ Department of Agronomy, M. S. Swaminathan School of Agriculture, Centurion University of Technology and \\ Management, Paralakhemundi, Dist. Gajapati, Odisha, 761211 \\ *Corresponding authors: rajibdasagro@gmail.com
}

Received: May 15, 2015; Revised received: December 7, 2015; Accepted: February 6, 2016

\begin{abstract}
An experiment was undertaken at the $\mathrm{C}$ block research farm of Bidhan Chandra Krishi Viswavidyalaya, Kalyani, Nadia, West Bengal, to find out the efficacy of some weed control methods in soybean (cv. Bragg) during kharif season of 2011-12 and 2012-13. The experiment was conducted in randomized block design (RBD) with 8 treatments in 4 replications. Treatments comprised of two different kinds of mulching (paddy straw @ $5 \mathrm{t} \mathrm{ha}{ }^{-1}$ and polyethylene), two herbicides (Flumioxazin @ $30 \mathrm{~g}$ a.i. ha ${ }^{-1}$ as pre-emergence and Quizalofop-ethyl @ $50 \mathrm{~g}$ a.i. ha ${ }^{-1}$ as post-emergence) alone and in combination, twice hand weeding at 25 and 50 days after sowing (DAS), integrated approach of Flumioxazin @ $30 \mathrm{~g}$ a.i. ha $^{-1}$ as pre-emergence along with one hand weeding at 25 DAS and one weedy check treatment. Among the weed control treatments, twice hand weeding at 25 and 50 DAS resulted the highest control of weeds $\left(5.91 \mathrm{gm}^{-2}, 6.09 \mathrm{gm}^{-2}\right.$ at 30 DAS and at harvest respectively) and produced the highest grain yield at harvest $\left(2797 \mathrm{~kg} \mathrm{ha}^{-1}\right)$, followed by Flumioxazin @ $30 \mathrm{~g}$ a.i. ha ${ }^{-1}$ as pre-emergence along with one hand weeding at 25 DAS, straw mulch @ $5 \mathrm{t} \mathrm{ha}^{-1}$, polyethylene mulch and combination of Flumioxazin @ $30 \mathrm{~g}$ a.i. ha $^{-1}$ as pre-emergence + Quizalofop-ethyl @ $50 \mathrm{~g}$ a.i. ha ${ }^{-1}$ as post-emergence.
\end{abstract}

Keywords: Efficacy, Kharif, Soybean, Weed control, Weed index

\section{INTRODUCTION}

Soybean (Glycine max [L.] Merr.) is an important oil seed crop that is widely grown as a valuable source of protein and vegetable oil. India accounts $2.4 \%$ of the world surface area, yet it supports $17.5 \%$ of the world population. Introduction of high yielding varieties, increased level of irrigation, improved farming technologies, fertilizers and pesticides have helped us to make self sufficiency in food grain production. According to ministry of agriculture, total food grain production of India was 241 million tones in 2010-11 crop years which will have to be increased to meet the mounting future domestic food grain demand. At present, most pressing problem is protein deficiency in our daily diet due to high cost and lack of conventional animal protein. About $40 \%$ population of India suffers from under developed physical and mental capabilities due to protein deficiency. Hence some cheaper alternative source of vegetable protein is necessary. Cultivation of soybean [Glycine $\max (\mathrm{L}$.) Merrill] has shown possible way out to this problem. One of the major constraints in soybean production is weed problem. It is heavily infested with grasses, sedges and broad leaved weeds. Competition from weeds reduced seed yields by $32 \%$ to $96 \%$, compared to when weeds were removed (Kushwah et al., 2005). If soybean weeds not controlled at critical period of weed crop competition (during first 30 days of sowing) reduces the yield of soybean from 58 to $85 \%$ depending upon the type and weed intensity of infestation (Govardhan et al., 2006 and Jadhav, 2007). It has been shown that soybean yields can be reduced if weeds are not controlled (Abdelhamid et al., 2008, Vollmann et al., 2010 and Mohammadi and Amiri, 2011). Several herbicides have been reported to control weeds in soybean but none of these can manage all the weeds efficiently. Unavailability of adequate labourers during peak crop weed competition period and difficulty in mechanical means also aggravate the situation. However, reliance on chemical herbicides has led to environmental contamination by the presence of herbicidal residues in soil, water and plants, shift in weed flora, appearance of resistant weed species and threats to human health (Bhowmik and Mandal, 2001; Bhowmik and Ghosh, 2002). In view of this, the present research work was conducted with the objectives to study the efficacy of some weed control methods in soybean during kharif season.

\section{MATERIALS AND METHODS}

Field experiments were conducted during June to October of 2011 and 2012 at the ' $C$ ' block research farm of Bidhan Chandra Krishi Viswavidyalaya, Kalyani, Nadia, West Bengal. The experiment was laid out in randomized block design with four replications. Variety 'Bragg' (medium height, determinate habit and 120 days duration) was used in the study. Rhizobium cul- 
ture (Brady Rhizobium) was mixed properly with the seeds half an hour before sowing and kept in shade for drying. Seeds were sown@100kg ha ${ }^{-1}$ in furrows at a depth of $5 \mathrm{~cm}$ made with the help of tynes maintaining $45 \mathrm{~cm}$ row spacing followed by covering with soil. The crop was fertilized with a common basal dose of $\mathrm{N}: \mathrm{P}_{2} \mathrm{O}_{5}: \mathrm{K}_{2} \mathrm{O} @ 25: 60: 40 \mathrm{~kg} \mathrm{ha}^{-1}$. The soil was clayloam alluvial soil (Inceptisol), almost neutral in soil reaction, having $\mathrm{pH} 6.73$, organic carbon $0.698 \%$, available nitrogen $286.35 \mathrm{~kg} \mathrm{ha}^{-1}$, available phosphorus $26.34 \mathrm{~kg} \mathrm{ha}^{-1}$ and available potassium $305.68 \mathrm{~kg}$ ha ${ }^{-1}$. The treatments included $\mathrm{T}_{1}$ : Weedy check; $\mathrm{T}_{2}$ : Hand weeding twice at 25 days after sowing(DAS) and 50 DAS; $\mathrm{T}_{3}$ : Paddy straw mulching @ $5 \mathrm{t} \mathrm{ha}^{-1} ; \mathrm{T}_{4}$ : Polyethylene mulching (black coloured polyethylene of $0.05 \mathrm{~mm}$ thickness) ; $\mathrm{T}_{5}$ : Flumioxazin@30 g a.i. ha ${ }^{-1}$ as pre-emergence at $1 \mathrm{DAS} ; \mathrm{T}_{6}$ : Flumioxazin @ $30 \mathrm{~g}$ a.i. $\mathrm{ha}^{-1}$ as pre-emergence at $1 \mathrm{DAS}+$ one hand weeding at $25 \mathrm{DAS} ; \mathrm{T}_{7}$ : Quizalofop-ethyl @ $50 \mathrm{~g}$ a.i. $\mathrm{ha}^{-1}$ as post-emergence at $20 \mathrm{DAS}$ and $\mathrm{T}_{8}$ : Flumioxazin@30 g a.i. ha ${ }^{-1}$ as pre-emergence at 1 DAS + Quizalofop-ethyl@50 g a.i. ha ${ }^{-1}$ as post-emergence at 20 DAS. Observations were made on types of weed flora, weed populations and dry matter, weed control efficiency (WCE), weed index (WI), yield attributes and yield of soybean. The analysis of variance method Cochran and Cox, (1963) was followed to analyze various data statistically. The significance of different sources of variation was tested by error mean square method of Fisher Snedecor's 'F' test at probability level 0.05. Standard error of mean $(\mathrm{SEm} \pm)$ and critical difference (C.D.) have been estimated to compare the differences between means.

\section{RESULTS AND DISCUSSION}

Weed flora in the experimental field: Grassy weeds were mostly predominant, followed by broad leaved weeds. Sedge weed population was very low in the experimental field. The most predominant weed species present in the experimental field were Echinochloa colona (20.3\%), Dactyloctaneum aegyptium (9.2\%), Digiteria sanguinalis(12.5\%), Eleusine indica (7\%), Cynodon dactylon(12\%) and Setaria glauca (2.1\%) among grasses, Cyperus rotundus(1.2\%) and Cyperus esculentus(0.7\%) among sedges and Phyllanthus niruri(6.2\%), Ananagallis arvensis(2.7\%), Physalis minima(6.1\%), Cleome viscose(2.3\%), Eclipta alba (2.8\%), Euphorbia hirta(3.4\%), Amaranthus viridis (3.2\%), Croton sparsiflorus(3.4\%) and Melilotus alba (2.9\%) among broad leaved weeds.

Weed population: At 30 DAS population of grassy weeds varied significantly at 5\% level due to different weed control treatments (Table1). The highest number was recorded in weedy check $\left(T_{1}\right)$ which was significantly higher than all other treatments. The lowest number was observed in combination of flumioxazin + hand weeding $\left(\mathrm{T}_{6}\right)$ treatment $(17.08)$, which was at par with twice weeding $\left(\mathrm{T}_{2}\right)$ and mulching treatments $\left(\mathrm{T}_{3}\right.$,
$\mathrm{T}_{4}$ ) resulting in effective control of grassy weeds. The highest broad leaf weed population was recorded in weedy check which was significantly higher than any other treatments and the lowest number was noticed in $\mathrm{T}_{6}$, closely followed by $\mathrm{T}_{2}, \mathrm{~T}_{3}$ and $\mathrm{T}_{4}$ which were statistically at par (Table1). At 30 DAS very low, out of which highest number of sedge weeds were observed in $\mathrm{T}_{1}$ (Table1). The most efficient treatments with respect to total number of weeds were $T_{2}$ and $T_{6}$, closely followed by $T_{4}$ and $T_{3}$ at $30 \mathrm{DAS}$. At harvest highest numbers of grass weeds were found in weedy check treatment $\left(T_{1}\right)$ which was significantly higher than other treatments. Lowest number of grass weed population was observed in twice hand weeding $\left(T_{2}\right)$, not significantly different from mulching treatments $\left(\mathrm{T}_{3}\right.$ and $\mathrm{T}_{4}$ ), Quizalofop-ethyl alone $\left(\mathrm{T}_{7}\right)$ and combination of Flumioxazin and Quizalofop-ethyl $\left(\mathrm{T}_{8}\right)$. Greater efficiency of controlling grass weeds by Quizalofopethyl was also reported by Singh (2005). Broad leaf weed population was also highest in weedy check $\left(\mathrm{T}_{1}\right)$, significantly higher than other treatments and the lowest number was found in $\mathrm{T}_{2}$, closely followed by $\mathrm{T}_{6}, \mathrm{~T}_{4}$ and $\mathrm{T}_{3}$, which were statistically at par (Table1). Highest number of sedge weed was observed in $T_{1}$ and all other treatments recorded insignificant number of sedge weeds (Table1).Significantly lowest total weed population at harvest was observed in $\mathrm{T}_{2}$, closely followed by $\mathrm{T}_{4}, \mathrm{~T}_{6}, \mathrm{~T}_{3}$ and $\mathrm{T}_{8}$. Two herbicides alone $\left(\mathrm{T}_{5}\right.$ and $T_{7}$ ) were less effective in this respect than other treatments $\left(\mathrm{T}_{4}, \mathrm{~T}_{6}, \mathrm{~T}_{3}\right.$ and $\left.\mathrm{T}_{8}\right)$, but were efficient as compared with weedy check.

Weed dry matter: At 30 DAS highest dry weight of grass weeds was recorded in weedy check treatment $\left(\mathrm{T}_{1}\right)$ and lowest in $\mathrm{T}_{6}$, closely followed by $\mathrm{T}_{2}, \mathrm{~T}_{4}$ and $\mathrm{T}_{3}$ (Table1), indicating efficient control of grass weeds with these treatments. Dry weight of broad leaf weed was highest similarly in weedy check $\left(T_{1}\right)$ having no significant difference with Quizalofop-ethyl alone treatment $\left(\mathrm{T}_{7}\right)$ indicating this herbicide not to be efficient in controlling broad leaved weeds. Out of different weed control treatments, weedy check $\left(\mathrm{T}_{1}\right)$ recorded the maximum growth of sedge weeds. The rest of the treatments recorded significantly lower growth of sedges than the earlier one (Table1).The highest total weed dry weight was recorded with weedy check $\left(\mathrm{T}_{1}\right)$ which was reduced appreciably due to different weed control practices. The most efficient treatments were $T_{6}$ and $T_{2}$, closely followed by $T_{4}$ and $T_{3}$. At harvest highest amount of dry matter of grassy weed was found to be in weedy check treatment $\left(T_{1}\right)$ and was noticed as lowest in $\mathrm{T}_{2}$, closely followed by $\mathrm{T}_{7}, \mathrm{~T}_{6}, \mathrm{~T}_{4}$, $\mathrm{T}_{8}$ and $\mathrm{T}_{3}$, which were statistically at par (Table1), indicating efficient control of grassy weeds with these treatments. Dry weight of broad leaf weed was highest in weedy check $\left(\mathrm{T}_{1}\right)$ followed by Quizalofop-ethyl $\left(\mathrm{T}_{7}\right)$, which were statistically at par indicating poor efficiency of controlling broad leaf weeds (Table1). In case of sedge weeds highest dry weight was recorded 
R. Das et al. / J. Appl. \& Nat. Sci. 8 (1) : 154 - 158 (2016)

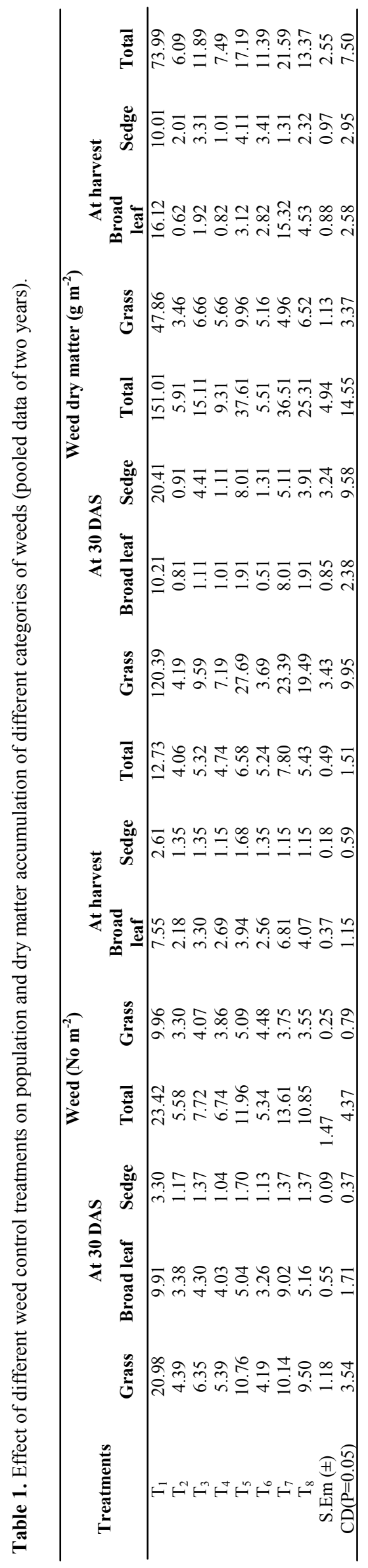

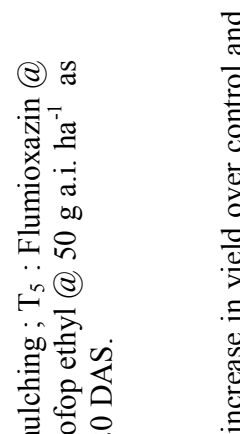

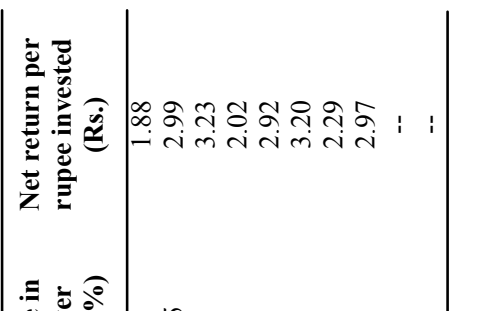

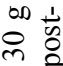

(2) दै

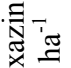

实

至 ${ }^{\infty}$

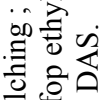

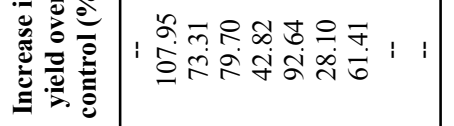

$\because(8)$

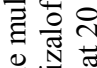

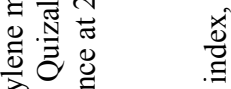

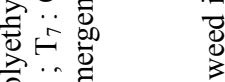

in

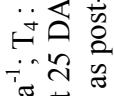

언

(8) $=\bar{j}$

000

急 豆

焉

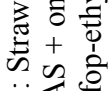

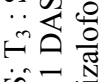

究吾言

욜

完

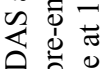

究

究.

过

它

bid on

(8) (8)

预 苟

$\therefore$.

$\rightarrow$ (2)

…

in

这主

$\ddot{ت}=\ddot{\infty}$

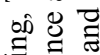

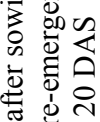

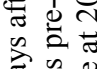

元

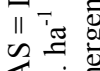

这.

bo

站突

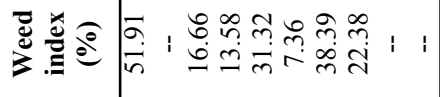

을 윰

ํㅡㄹ

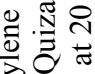

死 $\because$

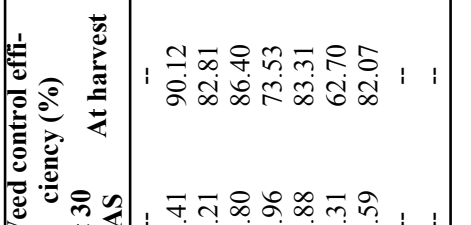

…

$\because$ 记

$\because \theta \frac{1}{b}$

ฐ

in 60

(8): 클

bo

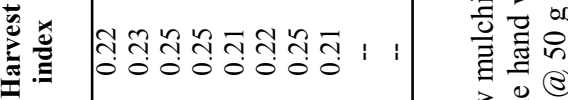

突方

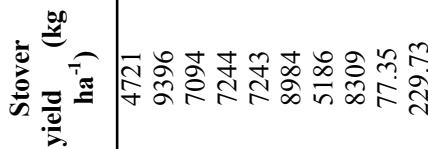

$\cdots$ 象

$\mapsto \overleftrightarrow{\circ}$

îे

:

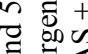

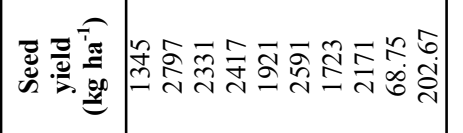

跤它

充䒕

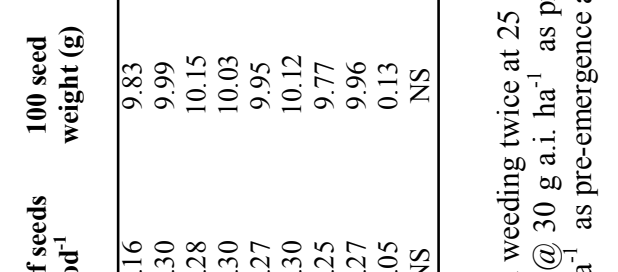

$\frac{0}{\sqrt{2}}$

ธี कิ

节市

苞苦

을 吾

0
0
0
0
0

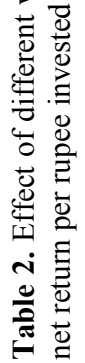

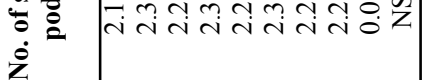

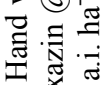

.. ⿵人一

$\sim$ 빙

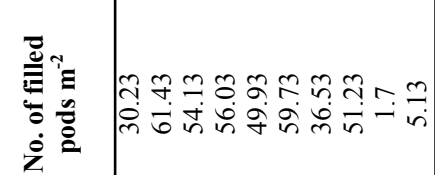

혼 (2)

ㄴ.

象前

它志

$\because \approx \ddot{\infty}$

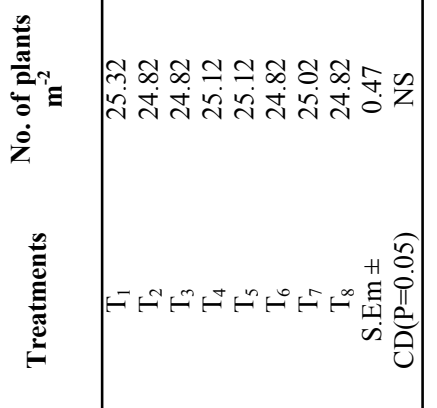

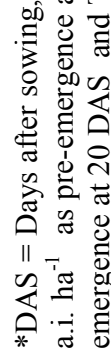


in weedy check $\left(\mathrm{T}_{1}\right)$ and the rest treatments were significantly lower than weedy check (Table1).The most efficient treatments with respect to total weed dry weight were $T_{2}, T_{4}$ and $T_{6}$, closely followed by $T_{3}$ and $\mathrm{T}_{8}$.

Yield and yield attributes: No any significant variation was noticed with respect to number of plants $\mathrm{m}^{-2}$. Plant density was almost uniform in all the treatments. The lowest number of filled pods plant ${ }^{-1}$ was recorded in weedy check treatment $\left(T_{1}\right)$ and all other treatments noticed significantly higher number over control. The highest number was observed in hand weeded twice plot $\left(\mathrm{T}_{2}\right)$, which was statistically at par with $\mathrm{T}_{6}$. The highest number of pods plant ${ }^{-1}$ of soybean with hand weeding treatment was similarly reported by Kumar et al., 2001 and Halvankar et al., 2005. Number of seeds pod $^{-1}$ did not vary significantly, however treatment $T_{2}$, $\mathrm{T}_{4}$ and $\mathrm{T}_{6}$ recorded the highest and $\mathrm{T}_{1}$ provided the lowest number of seeds pod ${ }^{-1}$ (Table2). No significant difference was recorded with respect to 100 seed weight in different weed control treatments (Table2). Kumar et al., (2001), however, reported increased seed weight with hand weeding twice. The lowest seed yield was obtained in weedy check plot (Table2), which was significantly lower than all other treatments. The reduction in seed yield due to severe weed competition at the critical crop growth period of soybean. Similar result were reported by earlier workers (Jha et al., 1983; Ilnicki and Horng, 1983). The highest seed yield was observed in twice hand weeded plots $\left(\mathrm{T}_{2}\right)$, which was significantly higher than all other treatments. Kumar et al., 2001, Reddy et al., 2003, Halvankar et al., 2005 and Singh (2005) found that twice hand weeding at critical growth period favour the growth and ultimately enhance yield. It indicated that manual weeding was most efficient in controlling weeds and increasing seed yield of the crop. Hand weeding with nirani could uproot all the weeds between and within the rows of the crop, at the same time loosen the surface soil, which minimize the competition from weed for growth resources as well as provided favorable situation for growth of the crops without any residual toxic effect. Next highest yield was obtained in $\mathrm{T}_{6}$, which was not statistically superior to $\mathrm{T}_{4}$ (polyethylene mulching). Lowest stover yield was recorded in $T_{1}$, which was significantly lower than all other treatments and highest yield was recorded with hand weeded plot $\left(\mathrm{T}_{2}\right)$, significantly superior to all other treatments. Among the treatments, straw mulch $\left(\mathrm{T}_{3}\right)$, polyethylene mulch $\left(\mathrm{T}_{4}\right)$ and Quizalofop-ethyl $\left(\mathrm{T}_{7}\right)$ recorded the highest harvest index $(0.25)$, however, $\mathrm{T}_{5}$ or $\mathrm{T}_{8}$ provided the lowest value $(0.21)$.

Efficiency of different weed control treatments: Twice hand weeding treatment $\left(\mathrm{T}_{2}\right)$ controlled all types of weeds very effectively, and minimizes the weed competition. As a result, it recorded the highest number of filled pods plant ${ }^{-1}$ and produced maximum seed yield $\left(2797 \mathrm{~kg} \mathrm{ha}^{-1}\right)$, where the increase in yield over control was $107.95 \%$ (Table2). The highest seed yield in hand weeded plot was similarly reported by earlier workers (Reddy et al., 2003; Halvankar et al., 2005 and Patra et al., 2005). Flumioxazin and hand weeding combination $\left(\mathrm{T}_{6}\right)$ recorded the second highest number of filled pods plant ${ }^{-1}$ as well as second highest seed yield of $2591 \mathrm{~kg} \mathrm{ha}^{-1}$ showing $94.25 \%$ increase in yield over control with lowest weed index (7.86). This treatment was efficient in increasing seed yield probably due to controlled germination of grass weeds due to pre-emergence application of Flumioxazin and the succeeding hand weeding operation which controlled all types of weeds. Productivity of polyethylene mulch $\left(\mathrm{T}_{4}\right)$ was followed by earlier treatments $\left(\mathrm{T}_{2}\right.$ and $\left.\mathrm{T}_{6}\right)$ due to its high weed control efficiency $(92.03 \%$ at harvest) and low weed index (14.16\%) with moisture conservation for the dry period and increasing soil temperature. Polyethylene mulch was effective in suppressing weed, increasing soil temperature (by $6^{\circ} \mathrm{C}$ and $4^{\circ} \mathrm{C}$ at $5 \mathrm{~cm}$ and $10 \mathrm{~cm}$ soil depth, respectively) and preventing soil moisture evaporation (Ramkrishna et al., 2006). Straw mulching $\left(\mathrm{T}_{3}\right)$ was also effective in controlling weeds and probably had the extra advantage of conserving moisture and providing aeration to soil. In this way, this treatment recorded higher number of filled pods plant $^{-1}$ and seed yield of $2331 \mathrm{~kg} \mathrm{ha}^{-1}$ with low weed index of $16.66 \%$. Patra et al., 2005; Idapuganti et al., 2006 and Ramkrishna et al.,2006 observed that straw mulch prevent weed germination and growth besides conserving some soil moisture. Herbicide combination treatment $\left(\mathrm{T}_{8}\right)$ was more efficient in producing seed yield through recording higher number of filled pods plant $^{-1}$ than when they were applied singly and Quizalofop-ethyl alone $\left(\mathrm{T}_{7}\right)$ was least effective in this respect (Table2).

Economic evaluations: Lower values of net return per rupee investment were recorded in weedy check (1.88) due to low productivity and in polyethylene mulch treatment (2.02) due to high cost of treatment (mulching materials). Net return per rupee invested was higher in twice hand weeding (2.99) due to high productivity and in combination of two herbicides (2.97) mainly due to low cost of treatment. Straw mulch $\left(\mathrm{T}_{3}\right)$ recorded the highest value (3.23) of net return per rupee invested though it produced lesser seed yield than that of twice hand weeding $\left(\mathrm{T}_{2}\right)$, combination of Flumioxazin and hand weeding $\left(\mathrm{T}_{6}\right)$ and polyethylene mulching $\left(\mathrm{T}_{4}\right)$ only due to the advantage of low treatment cost and there is a great scope to marginal farmers to earn more with this low investment eco-friendly practice. The straw could be incorporated into the soil for improving soil health and sustaining agricultural production. Combination of Flumioxazin and hand weeding $\left(\mathrm{T}_{6}\right)$ was equally effective as the earlier treatment $\left(\mathrm{T}_{3}\right)$ in terms of net return per rupee investment (3.20) by recording higher production as well as higher cost of cultivation as some investment was required here for labourers (for one hand weeding) but there was no plant toxicity due to low dose of herbicide. 


\section{Conclusion}

From the available data it can be concluded that for higher productivity, twice hand weeding at 25 and 50 DAS can be recommended. This treatment controlled all types of weeds flora during critical crop weed competition period, besides it loosen the soil without any harmful residual effect. But it requires involvement of high drudgery and is a costly practice. The problem of unavailability of labourer and higher investment could have some adverse effect on this practice. For marginal farmers, straw mulching @ $5 \mathrm{t} \mathrm{ha}^{-1}$ is more suitable and available practice which controls weeds effectively, provides aeration, conserves soil moisture and improves soil properties after incorporation. Combination of Flumioxazin and hand weeding is equally effective but it requires some investment (for one hand weeding).

\section{ACKNOWLEDGEMENTS}

I would like to thank the Incheck Research farm (' $\mathrm{C}$ ' block) and Department of Agronomy, BCKV, Mohanpur, Nadia, W.B. for providing all possible research facilities while executing the field experiment and laboratory analysis.

\section{REFERENCES}

Abdelhamid, M.T. and El-Metwally, I.M. (2008). Growth, nodulation, and yield of soybean and associated weeds as affected by weed management. Planta Daninha. 26 (4): 855-863.

Bhowmik, M.K. and Ghosh, R.K. 2002. Development and use of bioherbicides in the field of weed management. Proceedings of National Seminar on "Development and use of biofertilizers, biopesticides and organic manures", November, 10-12, 2000, Bidhan Chandra Krishi Viswavidyalaya, Kalyani, West Bengal. pp. 237-245.

Bhowmik, M.K. and Mandal, B.K. 2001. Biotechnological approaches to the management of weeds in Indian agriculture. Sci. Culture. 67(9-10): 275-280.

Cochran, W.G., Cox, G.M. 1963. Exprimental Designs. $1^{\text {st }}$ India Ed. Asia publishing House, Bombay, Calcutta, New Delhi. and Madras.

Govardhan, Joy D.S., A.K. Pathak and K. Varghese, 2006. Effect of pre-emergence herbicides on weed control and yield in soybean (Glycine $\max$ (L.) Merr.) Var. JS80-2. Agric. Sci. Digest. 26(4): 311-312.
Halvankar, G.B., Varghese, P., Taware, S.P. and Raut, V.M. 2005. Effect of herbicides on weed dynamics and yield of soybean. J. Maha. Agril. Uniy. 30(1): 35-37.

Idapuganti, R.G., Rana, D.S. and Pachauri, D.K. 2006. Integrated weed management in soybean [Glycine max (L.) Merrill] and its residual effects on succeeding wheat (Triticum aestivum L.). Indian J. Agril. Sci. 76(2): 125128.

Ilnicki, R.D. and Horng, L.C. 1983. Combination of several grass and broadleaf herbicides for post emergence weed control in soybean. International Proceedings of Biennial West African Weed science Society Conference. pp.1- 6 .

Jadhav, J.B., 2007. Effect of herbicides and crop weed competition on physiological aspects in soybean (Glycine $\max$ L.). M. Sci. (Agric.) In Crop Physiology, Dept. of Crop Physiology, College of Agric., Dharwad, Univ. Of Agric. Sci., Dharwad, India.

Jha, V., Tripathi, S.C., Mithyantha, M.S. and Sivasankaran, K. (1993). Efficacy of sethoxydim for the control of grassy weeds in soybean [Glycine $\max$ (L.) Merrill]. Proceedings of International Symposium, Indian Soci. Sci. Hissar. November 18-20, Vol. II, pp.161-162.

Kumar, P., Baghel, R.S., Singh, S.P. and Kumar, P. 2001. Weed management in soybean. Progressive Agri. 1(1): $38-41$.

Kushwah, S.S. and M.D. Vyas, (2005). Herbicidal weed control in soybean (Glycine max). Indian J. Agron. 50 (3): $225-227$.

Mohammadi, G.R. and F. Amiri, (2011). Critical period of weed control in soybean (Glycine max) as influenced by starter fertilizer. Austr. J. of Crop Sci. 5(11): 1350-1355.

Patra, A.P. and Haque, R. (2005). Herbicidal and eco-safety weed management in soybean in the entisol of west Bengal during wet season. Proceedings of the $20^{\text {th }}$ Asian -Pacific Weed Sci. Soci. Conf. pp. 356-360.

Ramkrishna, A., Hoang, M.T., Wani, S.P. and Tranh, D.L. (2006). Effect of mulch on soil temperature, moisture, weeds infestation and yield of groundnut in northern Vietnam. Field. Crop Res. 95(2/3): 115-125.

Reddy, S.M., Reddy, G.P. and Reddy, B.S. (2003). Weed management in soybean [Glycine $\max$ (L.) Merrill]. $J$. Oilseed Res. 20(2): 292-294.

Singh, G. (2005). Effect of chemical and mechanical methods on weed management, growth and grain yield of soybean [Glycine $\max (\mathrm{L}$.) Merrill]. Indian J. Weed Sci. $37(1 / 2): 131-132$.

Vollmann, J., Wagentristl, H. and Harti, W. (2010). The effects of simulated weed pressure on early maturity soybeans.European Journal of Agronomy 32 (4):243-248 